This is a prepublication version of the following article;

Mannay, D. and Morgan, M. 2013. Anatomies of inequality: considering the emotional cost of aiming higher for marginalised, mature, mothers re-entering education. Journal of Adult and Continuing Education 19(1), pp. 57-75.

Full article is available from - Official URL: http://dx.doi.org/10.7227/JACE.19.1.5

\title{
Anatomies of inequality: Considering the emotional cost of aiming higher for marginalised, mature mothers re-entering education
}

Dawn Mannay and Melanie Morgan

Cardiff University

\begin{abstract}
The Anatomy of Economic Inequality in Wales (2011) provides quantitative evidence for the pervasive nature of class-based inequalities in education, demonstrating that an individual in social housing is approximately 10 times less likely to be a graduate compared to those in other types of accommodation. This article moves beyond the baseline figures and argues that for marginalised, mature mothers re-entering education, the emotional cost is often one that they are unable to pay, and that practitioners and policy makers need to be aware of, and responsive to their situation so that retention and completion rates can be improved. The article presents case studies from two research projects, which aimed to explore and represent the educational experiences of working-class mature students in urban south Wales. The article focuses on the accounts of women who completed Access courses and gained places in post-1992 universities, focusing on their initial aspirations and later disappointments. The article examines the ways in which classed, gendered and relational positionings conflicted with their education trajectory and often contributed to their withdrawal from academia.

Keywords

Britain; higher education; class; marginalisation; aspiration
\end{abstract}




\section{Introduction}

The National Equality Panel's report An Anatomy of Economic Inequality in the UK

(Hills et al, 2010) demonstrated how inequalities in income and earnings in Britain are high, both temporally in relation to the position 30 years ago and geographically compared with other industrialised nations. Income and earnings are inherently linked with educational attainment; and applying this lens, the Anatomy of Economic Inequality in Wales (Davies et al, 2011) finds significant gaps in attainment related to residence in social housing and other indicators of relative poverty.

In relation to GCSE attainment pupils entitled to free school meals were found to be two and a half times less likely to attain grades A-C; and those living in social housing were 10 times less likely to be graduates compared to those in other types of accommodation. Living in poverty, then, can be seen as a reliable predictor of educational attainment and related opportunities in the employment market (Davies et al, 2011). Hills et al (2010) argue that a lack of awareness of the enormity of economic disparity acts as a constraint on policy interventions designed to contribute to reducing inequality; and sociologists and economists have found evidence that social mobility has remained stagnant and even decreased over the past 30 years (Davies et al, 2011). However, education can be seen as a cause and effect of inequality, suggesting that policy interventions could potentially increase social mobility

Exploring social mobility, Skeggs (1997) argues that at birth we are allocated into spaces of relative wealth or poverty and that these spaces pre-exist our agency and inform our access not only to institutional organisations such as education and employment but also to 'discourses and positions of conceivability, what we can envisage and what we perceive possible'. Aimhigher was an initiative set up in England to develop the educational progression and attainment of young people from 
disadvantaged backgrounds that focused on this idea of perception, arguing that raising the aspirations of disadvantaged young people can translate into them perceiving an academic trajectory as possible, and consequently achieving a place in higher education. In Wales, the commitment to widening access was demonstrated in the Reaching Wider initiative; which was modelled on the same premise and there were similarities and some collaboration between the two programmes (Hill and Hatt, 2012).

Evaluations of the programmes have demonstrated some success in widening participation to higher education for young people from marginalised communities (Hill and Hatt, 2012; Moore and Dunworth, 2011). However, although the statistics are encouraging, the evaluation does not provide an analysis of the differentiation and stratification between 'red brick' traditional and post-1992 'new' universities, which is often indicative of the persistence of classed inequality (Gallacher, 2006). This is important because access to type of education institution remains inequitable, with the most advantaged $20 \%$ of young people seven times more likely to attend the most selective universities than the $40 \%$ of the most disadvantaged young people (Milburn, 2012), a difference that has long-term consequences for students when they enter the employment market.

Furthermore, at the present time there are no available data on the number of 'Aimhigher' or 'Reach Wider' students who will not just enter higher education, but complete a first degree. This is important because widening access can only be interpreted as a success if such access engenders a qualified educational outcome. Entrance in itself does not expel the financial, cultural, social and psychological barriers that continue to act as obstacles to educational achievement (Bamber and Tett, 1999; Mannay, 2013a; Reay et al, 2010; Warrington, 2005); and although there 
was ongoing support for some students in the Aimhigher programme this of course was not available to all non-traditional students in higher education.

The concept of 'aiming higher' can also be seen as problematic because the action of perceiving possibility places a responsibility on the individual to succeed. Success necessitates individual agency but when individual duty becomes a moral imperative, one which silences structural constraints, aspiration is resonant of the concept of the elusive American Dream (Bullock and Limbert, 2003). In this way raising expectations by encouraging marginalised groups to take up higher education should be entered into cautiously, with an explicit understanding of battles just beginning rather than being won. If the challenge is not presented as ongoing at the outset, non-completion can easily be read as evidence of 'personal failure and pathology rather than social inequality and oppression' (Walkerdine, Lucey and Melody, 2001).

This is particularly important as the legacy of New Labour is a moral and contractual discourse which embraces the concept of reflective modernism and suggests an increased freedom for individuals outside of structural constraints (Giddens, 1991). Such neo-liberal assumptions have been seen to actively diminish the relative disadvantages of class, race and gender, and Britain has increasingly embraced a 'can do' philosophy (Thomson, Henderson and Holland, 2003). These discourses of agency often mask the structural constraints of class status, geography and the distribution of wealth for those who struggle on but ultimately 'can't do'.

In Young People and Social Change, Furlong and Cartmel (1997) describe the ways in which young people make sense of social inequalities in terms of their personal failings as an 'epistemological fallacy'. A decade on, Baker (2008) reiterates this premise, arguing that the belief that economic hierarchy is simply a reflection of 
individual ability and effort has become so pervasive even individuals in disadvantaged circumstances are convinced that they reside in a pure environment where success is primarily dependent on their personal skills and shortcomings.

Bamber et al (2006) argue that participation in higher education is inherently more risky, costly and uncertain for working-class groups and there is a need to consider how educational cultures can create and perpetuate disadvantage. Programmes such as Aimhigher, then, are not enough, for there needs to be an understanding that aiming is only a starting point for marginalised students, one that must be accompanied by ongoing support at the institutional level if retention rates are to be improved. Retention of non-traditional students is problematic and research synthesis has identified weak course match, unsatisfactory academic experience, lack of social integration, financial issues and personal circumstances as the primary reasons behind non-completion at the higher education level (Jones, 2008).

As Thomas and Jamieson-Ball (2011) argue, it is challenging to convert the results of retention synthesis into institutional interventions or a strategy that improves student retention and success. However, programmes such as 'What works? Student retention and success' offer strategies emphasising the importance of collaborative, student-centred learning and teaching, which facilitates staff-student interaction and enables staff to have a better understanding of their students (Crosling, Thomas and Heagney, 2008). This approach can be seen as a move away from discourses of individual failure and a step towards an acknowledgement of the need for structural change within institutions.

The conceptual model underlying 'What works?' recognises that rather than desiring a more homogeneous student body, or simply expecting non-traditional students to fit effortlessly into the existing status quo, institutions need to make 
changes themselves. This approach has demonstrated some success in previous research in the North East of England where universities have adapted their approach to support mature students in terms of timetabling and finance administration (Bolam and Dodgson, 2003). More recently, in England and Wales, a number of institutions have engaged with this philosophy and are beginning to assess the ways in which changes can be implemented in order to increase retention and completion rates among disadvantaged students (Thomas and Jamieson-Ball, 2011).

This article supports the current approach but argues that any intervention needs to be based on a clear understanding of the everyday barriers faced by nontraditional students. Although the simplified categories of barriers offered by retention research synthesis may be useful, groupings such as 'lack of social integration' or 'personal circumstances' (Jones, 2008) are often too generic to communicate the everyday practicalities and psychological conflicts that make the possibility of higher education untenable.

For this reason it is important that educators and administrators have access not only to categories of barriers, but also to holistic and detailed narratives which provide a more nuanced insight into the invisibility of everyday life for nontraditional students. As Reay (2004) argues, access to interpretative accounts offers an opportunity to develop more complex and differentiated representations of workingclass lives and contributes to making 'informed as opposed to ignorant policy decisions'. Intervention, then, should always be preceded by understanding, and this article contributes to processes of understanding by examining the ways in which classed, gendered and relational positionings conflict with education trajectories in a case study of three non-traditional students. 


\section{Methodology}

Places and spaces: The research sites

The geographical spaces that are home to the participants in all the studies are predominantly white areas in urban and rural south Wales, which have become the epitome of the classically disadvantaged community. The poverty yardsticks applied to the areas include those measuring high unemployment, high rates of teenage pregnancy, high numbers of lone-parent families and high take-up of free school meals.

According to the Welsh Index of Multiple Deprivation (Welsh Assembly Government, 2008), these research sites rank highly in terms of being some of the most deprived communities in Wales under the category education, skills and training. This absence of engagement with post-compulsory education can translate into residents who take up academic careers being forced to live at the interface between two discursively different worlds. Such a position often demonstrates the psychological consequences of spatial positioning of 'border crosser' (Lucey, Melody and Walkerdine, 2003), and this is something we will return to shortly.

\section{Research relationships}

The relationship between researcher and researched is key to the collection of rich and reliable data (Pole, 2007). Therefore, it is important to explicate the position of the researchers. Both researchers have lived within deprived areas in south Wales; there is, then, a shared sense of geography, which positioned us as 'researcher near' and influenced the design of the study. Additionally, as Parr (1998) contends, researchers are not simply academics but people with individual personal histories; and we had both re-entered education as adults. While mature students' experiences may be 
qualitatively different, they are by no means uniform (Reay, Crozier and Clayton, 2010); nevertheless, we came to the field with our own ideas, expectations and preconceptions.

Although this article does not intend to engage with debating insider and outsider dichotomies there remains the concern that we are 'experience near' (Anderson, 2002), which can intensify the need to guard against familiarity. Consequently, it was important to address our position as indigenous researchers and make a deliberate cognitive effort to question our taken for granted assumptions of what we thought of as familiar; and to consider the ethical issues of anonymity of place, participants, narratives and visual images (Mannay, 2010; 2011; 2013b). In combination with earlier strategies (Delamont and Atkinson, 1995), I, Dawn, was influenced by research that employed participants' visual data to render the familiar setting more perceptible (Gauntlett, 2007; Kaomea, 2003). Accordingly, participant-directed visual data collection techniques were selected to promote subject-led dialogue and to limit the propensity for participants' accounts to be overshadowed by the enclosed, self-contained world of common understanding. Participants featured in this chapter used the data collection techniques of photoelicitation $^{1}$, mapping ${ }^{2}$ and narrative ${ }^{3}$ (see Mannay (2010) for a full discussion of visual data production); data was then discussed in an elicitation interview privileging the interpretative model of auteur theory (Rose, 2001).

In order to acknowledge my own subjectivity and positionality, I, Melanie, undertook an autoethnographic exploration of my experiences of higher education and drew extensively from earlier indigenous studies in this area (Karach, 1992; Parr, 1998). This approach engendered an interest in the ways in which identity is a continual production that is relational, fluid, dynamic, situational and sometimes 
conflicting. For this reason, I adopted a theoretical framework consisting of a fusion of Foucauldian post-structuralism with psychoanalytic ideas (Henriques et al, 1984). A series of interviews were carried out with each participant to gain an understanding of how working-class, mature student mothers construct, negotiate and manage identity within a kaleidoscopic mix of social, structural, economic and historical factors.

\section{Participants}

For this article, we present analysis from across the two projects. I, Dawn, selected data produced with two mothers from the research sample. Both mothers, Caroline and Emma ${ }^{4}$, completed Access courses and gained places in post-1992 universities. In the following sections I, Dawn, focus on their initial aspirations and later disappointments, and examine the ways in which classed, gendered and relational positionings conflicted with their education trajectory and contributed to their withdrawal from academia. I, Melanie, also focus on the ways in which mature students can be alienated by the system, dislocated from their past roles and status and experience a 'partial loss in their sense of self' (Karach, 1992). I introduce the reader to Tanya, a single mother of two young children who is successfully negotiating the third year of her degree, exploring how this journey has been maintained.

\section{Introducing Caroline}

Caroline is white, working class and 38 years old, and is in a stable relationship with her husband of 16 years. They both grew up in council housing in Hystryd and took out their first mortgage, when Caroline was 18, on an ex-council house in the heart of Hystryd. They have since moved to a privately owned home on the periphery of 
Hystryd. Caroline's husband works full-time and they have three children, two sons aged 13 and 8, and one daughter, Sophie, who is 15 .

Caroline left school with no academic qualifications and found herself constrained within the traditional three Cs - catering, cleaning and caring - with an associated wage that acts as 'a large No Entry sign on every ordinary pleasure in today's consumer society' (Toynbee, 2003). Caroline re-entered education as an adult and continued to engage in part-time work. Her experience illustrates the complex set of emotional challenges inherent to working-class upward social mobility in terms of gender, class and identity.

\section{Legitimate motherhood}

Caroline re-entered education as a mature student, after an early academic experience tinged with feelings of inadequacy and a career of low-paid employment in the cleaning sector that she describes as 'a load of shit'. Caroline wanted to escape the notion that she is a defiler because of the day-to-day nature of defiling material encountered (Davidoff, 1976) and improve her family's prospects by investing in education.

Although Caroline had the support of her 'proud' husband and her extended family, returning to education was difficult. Caroline felt that she was no longer a legitimate mother or wife because she could neither offer a high level of fiscal support nor spend an adequate amount of time nurturing her children and keeping the home clean, as prescribed in the ideal notion of the new motherhood (Benn, 1998; May, 2008). 
Housework - 'It's not too bad with these irons they got now'

As Page and Jha (2009) maintain, gendered labour divisions within the home are a cross-cultural phenomenon, and Wales is no exception. An earlier study exploring housework across three generations of Welsh women found that despite their greater rhetoric of egalitarianism women continued to have the main responsibility for housework, even when involved in paid employment (Pilcher, 1994).

Warren (2003) argues that alongside a gender-based approach to the study of the domestic division of labour it is important to acknowledge the role of class. Analysing data from the British Household Panel Survey, Warren found that workingclass dual-waged couples were more likely to fall into the time poverty category than their middle-class counterparts. Furthermore, women in these couples contributed a proportionally higher share of caring and domestic work than both their partners and women in professional roles, who can often afford to contract out domestic tasks.

When I asked Caroline to take photographs that represent everyday life she constructed many of her ideas of 'place and space' with images of housework. Caroline describes ironing as her 'pet hate' but explains that she does not cut any corners, ironing sheets, pillow cases and quilt covers as well as clothes for five people. Caroline tells me 'it's not too bad with these irons they got now' and jokes 'I'm not there all day like I used to be, just half a day'. In the interview I comment that ironing for five people must take a considerable amount of time and Caroline replies:

Yeah it does, it do, but I mean I'm lucky in the way that, you know, other things, you know, I get help with. 
The 'other things' include cooking and vacuuming but Caroline talks about her high standards for correct ironing and says 'it's just me that irons'. Although her husband took on a limited domestic role that was well received by Caroline, his cleaning was peripheral, and Caroline was careful not to allow this 'help' to impinge on her own role and standard of cleaning.

As Maushart (2001) argues, to maintain the adage 'a woman's place is in the home' there may be a need to guard against partners' involvement in the domestic sphere: acting as a 'gate keeper'. This is particularly significant as the concept of cleanliness is intrinsically linked to the notion of maintaining a respectable workingclass femininity. As Evans (2006) contends, dirt assumes a heightened importance when the metaphorical stereotypes of your class are muck, filth, dirt and waste products.

In Wales, a colonised nation, such analogies can have a fervent and more sustained influence over the lives of women. For example, Aaron et al (1994) argue that the moral imperative to adopt an English middle-class model of femininity put forward in the 1847 Report of the Commissions of Inquiry had a pervasive influence over the identities of generations of Welsh women, which has placed cleanliness as central to attaining an acceptable form of idealised Welsh working-class femininity.

Caroline invests her identity in the domestic sphere and the ideology of cleanliness. There is a need to manage a moral presentation of the self (May, 2008), and psychological ideology of the 'good wife' can be maintained and remade through the act of housework. More importantly, taking on domestic tasks offers an opportunity to display a normative femininity characterised by her 'capacity to care' for her children (Holloway, 2006). 


\section{Motherhood - 'I wish you never started that nuniversity'}

Social and moral identities are intricately bound up with parenting; and keeping the home clean is often viewed as an essential element of motherhood, even in the prescribed ideal notion of 'new motherhood' (May, 2008). These moral boundaries lay out respectable and acceptable benchmarks, which act to police women and trap them in patriarchal relationships, but in modernity the goalposts have moved so that motherhood entails not only a responsibility for the domestic sphere and fulfilment of children's emotional needs, but also the ability to provide financially for the family. Despite Caroline's attempts to do her academic study late at night, when her children slept, her youngest son was particularly upset by the constraints that studying placed on her time telling his mother 'I hate that nuniversity; I wish you never started that nuniversity'. Caroline draws from a discourse where a morally tenable feminine identity is intricately bound up with nurturing children (Holloway, 2006) but motherhood is tied not only to the provision of care but also to the provision of resources (May, 2008).

The pre-existing world of work for working-class women like Caroline is formed from a history in which the woman who must work should ideally be engaged with motherhood or lower-level, gender-stereotyped paid employment (Pilcher, 1999). Caroline followed this trajectory until her decision to enter higher education, which began to impinge on her ability to perform the expectations of domesticity, motherhood and provision. The emotional complexities involved in challenging the expected trajectory of the working-class woman eventually result in Caroline letting go of the elusive American Dream.

After completing two years of part-time Access and two years of full-time study at a post-1992 university, Caroline became another figure in the statistics for 
non-completion. At university Caroline felt that she transgressed social and moral identities bound up with gender and classed specific parenting. After leaving university Caroline returned to the employment sector that she had previously described as 'a load of shit', applying for jobs that could be found under the category of the 'dirty work of neoliberalism' (Herod and Aguiar, 2006).

Caroline hoped for a new life, a professional status and to be an inspiration to her children. In her initial journey through further education, Caroline felt supported in an environment characterised by teachers who maintain an ethic of care which 'privileges the needs and interests of their students' (Jephcote, Salisbury and Reese, 2008), and able to succeed academically. However, Caroline's experience of higher education was one in which she felt unsupported; and consequently these aspirations, for her present and for her children's futures, had to be cooled out when she left university.

Caroline was only behind with two pieces of coursework but did not feel that she could ask for an extension; her difficulties did not fulfil the criteria of a 'special circumstance'. In this way the everyday difficulties became unlivable, but also normalised into a space where a lack of clear understanding belied assistance or intervention.

\section{Introducing Emma}

Like Caroline, Emma is white, working-class, and is in a stable relationship with her partner of 15 years. They have both worked in low-paid unqualified posts and their employment trajectory has been characterised by insecurity and long periods of unemployment. They grew up in council housing in Hystryd and still live in council housing on what is arguably one of the most troubled streets in Hystryd. 
Emma has lived in the area for all of her 32 years and is 'Hystryd born and bred'. However, she wants her children to live in a different area and decided to take an Access course followed by a degree pathway as an escape route to a new and better future. Emma's experience demonstrates the psychological consequences of the spatial positioning of 'border crosser' (Lucey, Melody and Walkerdine, 2003), and a learner identity characterised by 'in-betweeness' (Hewitt, Hall and Mills, 2010) in terms of ideologies of class and education.

\section{Border Crosser}

Emma's transformation from 'stay at home mum' to college student elicited a range of negative emotions in her family, such as inadequacy, anger and envy, which have been apparent in other studies of working-class upward social mobility (Lucey, Melody and Walkerdine, 2003). Emma created maps of her social world and narratives of her aspirations and fears. The creation of this visual and narrative data elicited a range of conflicting emotions about her educational trajectory, and how this had acted to isolate her from her extended family and the wider cultural milieu of Hystryd.

\section{Uneasy hybrids - 'I got to let go of my family'}

In the process of creating visual data Emma began to realise the extent to which the space of her childhood home had changed since her transformation from 'stay at home mum' to college student. Our conversation about this difference evolved from a hand-drawn image in Emma's place and space map depicting the college where she undertook an Access course. 
Emma was brought up on the council estate and her parents still live in the house where she was born, whilst her siblings and extended family live in the neighbouring streets and form what Bott (1971) describes as a 'close-knit' network. As discussed in the opening section Emma is unhappy with her home in the centre of social housing, 'where I am it's just horrible; I don't think you'd like to live there', and for Emma college is seen as a potential vehicle of social mobility, which can provide the opportunity to move home. However, post-compulsory education is uncharted territory for Emma's family, and engaging with this new place creates a change in Emma and recognition of a process of separation.

D'you know what I mean, it's weird; it's like I'm not even there no more; I'm, I don't know ... it's just weird, like I'm totally in a different place to them.

For Emma visiting the 'new world' offered through the local college ideologically locates her 'totally in a different place to them'. Emma uses the description 'weird' twice in the extract indicating that she was not expecting to feel 'out of place' with her family, or that her family would feel 'out of place' with her. The disruption of the close relationship she had previously enjoyed with her mother is illustrated in the following extract.

I think there was a bit of jealousy, see, at the start of me joining college; ... yeah it was, like ... I don't know it, ah, ... it's weird, right, saying this, but the first couple of months, I think there was, like, a bit of grief, you know what I mean? [laughs] ... it was like grief, like I lost something. 
Emma speaks about 'grief' and feeling that she 'lost something' and, despite the laughter in our talk, Emma communicates the painful process of belonging to and distancing herself from her family, a process which has been documented by some who made the journey from working-class girl to middle-class academic and have recorded, theorised and lived the life of alienation (Walkerdine and Lucey, 1989).

As Emma aspired to move on, educationally and geographically, her mother fought for things to stay the same, for a preservation of place, as she struggled to 'fix, to stabilise the identity of a particular place'. The family has remained in the same social milieu, defining its identity through counter position to the other that lies beyond, but Emma's desire for a new, 'other' life places the other that lies beyond paradoxically within (Massey, 1994).

Within the space of the college Emma constitutes part of an 'affinity group' that is bonded primarily through shared endeavours, goals and practices (Gee, 2003) but beyond this educational enclosure, groups are built through shared race, gender, nation, ethnicity or culture. Emma's family and friendship circle, like all social groups, has a set of norms and values that determine certain sorts of patterns and ways of filling them out in everyday practices (Goffman, 1959).

In Emma's social milieu college is 'not for the likes of us', and her account documents the inherent difficulties of leaving and yet remaining in the old world, especially in close-knit networks, where relationships with and among kin have always been regarded as relatively permanent (Bott, 1971). Living in a marginalised space guides our understandings of who we are and simultaneously who we are not (Sutton, 2009), and in Emma's account we see how old worlds cannot sit easily with new worlds, and the ways in which social mobility was seen as a force that would potentially destroy familial relationships. 
Emma was positioned between two discursively different worlds and subject to the emotional cost of what Lucey, Melody and Walkerdine (2003) refer to as hybridity, an irresolvable positioning of in-betweeness. The psychological cost is ongoing and painful; as Emma says there is 'grief', a feeling that she 'lost something'. The cost of this slow symbolic death is destructive, but again it is not something that would be viewed as a 'special circumstance'; it is a psychological rather than a physical death.

Across the Access journey Emma felt that there was a shared understanding of being a border crosser among her peers, and a tacit understanding from tutors who were sympathetic in allowing extensions and offering support. However, entering higher education Emma found that she was isolated: an uneasy hybrid (Lucey, Melody and Walkerdine, 2003) in a social milieu where neither peers nor tutors had an understanding of the classed incongruity of her position. Emma's battles lay in an internal realm and in the university they did not fit into the official categories needed to access support. After completing her first year, Emma, like Caroline, becomes another non-traditional student among the non-completion statistics, having to acknowledge her family's warning that education is 'not for the likes of us'.

\section{Introducing Tanya}

Tanya is a 34-year-old single mother of two sons, aged 14 years and 15 months old, who is in the third year of a nursing degree at a local post-1992 university. Tanya resides in Milburn, a council estate in the south Wales valleys, a community notorious for high levels of deprivation and pathologised both locally and in wider media. However, in recent years, much work and funding, from the Welsh Government and National Lottery, has gone into community regeneration of the area, particularly in 
terms of education. There have been initiatives to develop aspirations, led by local community role models, and Tanya could be understood as a success story; an exemplar as a member of the community in terms of educational and social mobility.

\section{Life before education}

Tanya left school with no educational qualifications and worked as a barmaid at a local club. At 20 years old, Tanya became pregnant but the pregnancy was unplanned and her boyfriend left her for another woman whom he had also made pregnant. Tanya describes her life after her first son was born as centred around cleaning and caring for the needs of her baby and her family as illustrated in the following extract.

I would go to my mother's ... I would clean my house in the morning and then go down there [Tanya's mother's house] and clean her house, then I would go to my Nan and see to my Nan, go back to my mother, make tea, come home put the baby to bed - do it ... sort everything out - do it all again the next day and that was it until [son] was about nine.

Once again we see an identity centred around motherhood, family and the domestic sphere. It is a form of idealised Welsh working-class femininity that is central and prolific in many post-industrial communities, echoing the legend of the 'Welsh Mam' (Rees, 1988). However, as Hollway (2006) reminds us 'women who are mothers are not only mothers' and there came a point when Tanya wanted to move into a space outside of the routines of the acceptable working-class femininity and the ideology that motherhood is a mutually exclusive enterprise. 


\section{Education, aspiration and affect}

Women with dependent children often experience academic study as particularly challenging (Marandet and Wainwright, 2006); and gendered expectations around household chores and childcare mean that academic study is often viewed as an 'extra-curricular' activity or hobby, to be fitted into, but not disrupt, an already busy schedule. In order to manage conflicting demands, time needs to be strategically negotiated and planned and this is particularly so for single parents (Obsborne, Marks and Turner, 2004).

Support systems of wider family members and friends are often asked to help out with childcare; and thus academia is pursued depending upon the cooperation of others and under conditions of constraint. Mothers in education often discuss experiencing feelings of guilt which are expressed in terms of neglecting or compromising their familial relationships and role as mother. In terms of both gender and class then, there are some important implications for subjectivity: although Tanya discusses the positive factors of entering education in the extracts below, this journey is not without cost:

I'd get up in the morning - I'd still do my cleaning - put [son] to school and it was like switching off then ... you had a purpose to get up and do something ... New Year's Eve and I was thinking good God this time last year I would have been out, because I had been out every New Year's Eve and I was sitting there holding my head, I remember holding my head thinking I am stuck in here - but I thought no, I will do it, I will ... I'm pleased to tell you, you have been accepted. Well I just burst out crying ... I was hysterical ... and I was 
going oh thank you, you don't know how much all this means to me and all this - I feel emotional telling you.

Tanya could be understood as a poster girl for the regeneration project; however, as Walkerdine (2011) suggests, addressing issues of intergenerational poverty and social mobility via higher education is far more complicated than raising aspiration. For the working-class subject, the discovery of aspiration and desire to succeed can be felt as threatening to self and others, creating tensions between autonomy and belonging, safety and risk, statis and transition: a complicated cultural and psychosocial phenomenon (Walkerdine and Jimenez, 2012).

Tanya's transition is one laden with affect and her desire to be a nurse is not experienced in a straightforward way for she is deeply ambivalent, torn between expectations of her centred around her old life and identity - 'I would still do my cleaning' - and the possibility of new becomings, being someone else, somewhere else. Although thrilled at being accepted to university and managing to stay in education to pursue her nursing degree, like Emma, Tanya has become a 'border crosser' (Lucey et al, 2003) and cultural and gendered expectations around motherhood are a constant threat to her studentship: both a source of anxiety and conflict. For Tanya, it is not lack of aspiration that is problematic, but rather the complex relations and practices within which Tanya's aspiration is ensconced or anchored (Walkerdine, 2011).

In their study, Britton and Baxter (2001) found that managing conflict and changes to identity was more arduous to working-class mature students than their middle-class counterparts, and that negotiating alteration in family relationships was particularly difficult for female students in comparison to males. The following 
extract highlights the precarious nature of Tanya's position and illustrates the complex set of emotional and relational challenges inherent to working-class upward social mobility. Tanya describes a day when her son was ill, she was pregnant and just before going into her first year examinations she received an abusive telephone call from her sister.

Some things she has said. It is awful. Dreadful what she has said - like phoning social services, you should be ashamed she said, you should be in the house with the baby, ... you shouldn't be in uni and I said Scott [partner] what can I do, I can't win - whatever I do is wrong, it's not, it's not good enough .... I do feel guilty coz like I said to Scott, even a few weeks ago - I am finishing, I am quitting, I said I need to go back to what I used to be before - my mother, I need to be there all the time and doing. He said Tan you can't, you can't and then I convince myself I gotta, I gotta finish, I can't do this any more - I should be there for my family. But I think well I can't be.

Despite having the support of her partner at the time, wider family expectations, envy and culturally gendered discourses around motherhood collided with Tanya's own ambitions and desires with painful effect. Judgement and conflict from her sister and the threat of state intervention elicits guilt and a longing for her old life which Tanya manages by trying 'not think about it ... try to block it out and carry on'. Indeed this was manifest during our interview when Tanya managed her sister's constant phone calls, 13 in one hour, by blocking them out and carrying on; she managed to ignore them far better than I. Since early on in her educational journey, Tanya experienced education as a 'place to switch off ... before having to 
come back to reality'. Despite the tensions that her degree has created and exacerbated, for Tanya education is simultaneously a place where she feels she can escape and, in that respect, university has become a place of safety.

\section{Strength and survival}

Tanya sought support from another woman student on her course who was living locally to her and in similar circumstances. This advice and guidance developed into a reciprocal arrangement whereby the women studied together and 'bounced off each other', learning became a shared endeavour and their relationship developed into a firm friendship without which Tanya claims she could not have completed the first undergraduate year. Her position in higher education became more precarious when her maternity leave meant that she had to join the next year's cohort. However, this situation was eased via both women's strategic planning and a social networking site engendered a virtual relationship that acted as a point of contact and meant that on her return from maternity leave Tanya once more had a woman, connected to her community, she could identify with and share her journey with.

As Tanya had come from the previous year's cohort, this positioned her as the expert, and she gained much pleasure and satisfaction from providing advice and guidance. This relationship also developed into a friendship and having her support recognised and appreciated (unlike at home) was very much valued by Tanya. During my visits she showed me the cards and notes of encouragement, thanks and congratulations that the women had exchanged, which demonstrated the salience of their relationships.

Understood within the context of the post-industrial communities of which these women are part, these connections are important as they gain strength and 
support through their sameness and they provide a sense of belonging, of keeping together, of continuity and safety. They are in fact drawing on the same resources which historically in times of difficulties held their communities together. The women have themselves established an informal system of 'paying it forward' or generalised reciprocity. It is this mutual and acknowledged support that is a key element to Tanya staying in higher education. In psychoanalytic terms the women may be understood as transitional objects which allow Tanya to feel safe - contained or held (Bick, 1987; Walkerdine, 2010, 2011), giving her a continuity of being as she moves forward in her educational trajectory, whilst simultaneously anchoring her self to her past and her culture. Sadly, these informal support networks are not always available or easily accessed. Their absence could be assumed to result in the affective pull of one's old life and identity to become stronger, preventing movement and change but providing continuity and security in the safety of familiar identities and ways of being.

\section{Concluding remarks}

As Butler (2004) suggests, agency always exists with paradox; she explains, 'If I have any agency, it is opened by the fact that I am constituted by a social world I never choose'. Thus, for Caroline, Emma and Tanya, being a non-traditional learner had to be accommodated within their wider lives, 'by a social world I never choose', which are gendered, classed and often incongruent to the world of higher education. The students' journeys involved overcoming significant barriers to engaging in formal learning, but these barriers were often at the level of the psychosocial, making them invisible, and unable to achieve the categorisation necessary for further support.

Caroline and Emma both succeeded at Access level and began degrees but later abandoned their studies; the journey was too painful and they felt that there was 
little understanding within their institutions. As Milburn (2012) argues, universities could be 'doing a lot more - in a far more focused way' to contribute to a more socially mobile society and this is why an application of the psychosocial is necessary; institutions need to have an understanding of barriers at the affective level, otherwise programmes to widen access and retain students are designed solely from a surface understanding of class, and this is inadequate.

Tanya has successfully, although not painlessly, negotiated the journey into higher education and her account offers an insight into the everyday negotiations which have achieved this position. For Tanya, it was the informal support network system that offered a point of contact with someone like herself that was central in providing the motivation to carry on in higher education. This anchoring to the past, by befriending peers with a similar historical and cultural heritage, both face to face and through social networking sites, allowed Tanya to move forward on her educational journey. In terms of institutional policy, this would suggest that it could be useful to set up informal networks and peer buddy systems within universities as a support system for non-traditional students entering higher education.

Moreover, the cases discussed in the current paper, along with further participants' accounts in the wider research sample, have raised concerns with the mitigating circumstances policies within institutions of higher education. For this reason, it is recommended that universities carefully evaluate their individual guidelines in relation to their suitability and effectiveness for meeting the needs of mature students. Additionally, if universities are to be involved in projects of widening access, it will also be important to consider staff awareness and offer training and guidance for university academic and administrative staff so that they can work with a diverse cohort of students in a sensitive and effectual manner. 
Intervention, then, should always be preceded by understanding, and individual narratives can offer a more nuanced insight into the psychological difficulties faced by non-traditional students. Access to complex and differentiated representations of academic journeys can potentially open up new discourses, from which changes can be implemented in order to increase retention and completion rates among disadvantaged students, so that they can successfully 'Aimhigher' and escape intergenerational anatomies of inequality.

\section{Notes}

1 The techniques of self-directed photography and photo-elicitation, or 'photo-voice' as it is sometimes called, have been used successfully in a range of research studies. In this study participants were each provided with a camera and asked to take a series of photographs depicting meaningful places, spaces and activities. The photographs then formed the basis of an interview where I engaged in a tape-recorded discussion with each participant. Further discussion of the technique can be found in Mannay (2010).

2 The technique of mapping is an activity where participants are asked to draw a representation of a specific geographical space of journey. In this study participants were each provided with art materials and asked to make a series of maps depicting meaningful places, spaces and activities. The maps then formed the basis of an interview where I engaged in a tape-recorded discussion with each participant. Further discussion of the technique can be found in Mannay (2010).

3 In narrative approaches, stories provide an analytical frame for the study of mental life as well as the study of social conditions. In this study participants were asked to write narratives from the retrospective perspective of their childhood self describing 
who they wanted to become, their positive possible self, and who they feared becoming, their negative possible self. This activity was repeated from the perspective of the present and participants again wrote a narrative of possible positive and negative selves.

4 The names Caroline, Emma and Tanya are fictitious and were chosen to maintain participants' anonymity.

5 The place names Hystryd and Milburn are fictitious and were chosen to maintain anonymity.

\section{Acknowledgements}

We would like to acknowledge the participants, Caroline, Emma and Tanya, who made this article possible, and also Professor John Fitz, Professor Emma Renold and Dr Bella Dicks for supervising Dawn's research project and Professor Valerie Walkerdine and Dr Gabrielle Ivinson for supervising Melanie's research project. We would also like to thank the organisers of the 2011 Forum for Access and Continuing Education conference, Lifelong Learning and Community Development, where we began to consolidate some of the ideas presented in this paper. We are grateful to Professor Michael Osborne and the reviewers for their encouragement and invaluable comments on earlier drafts of this paper; and the editorial team at the Journal of Adult and Community Education for their support. The two doctoral research projects from which this article is drawn, titled Mothers and Daughters on the Margins: Gender, Generation and Education and Experiences of Mothering: a Psycho Social Study, were both funded by the Economic and Social Research Council. 


\section{References}

Aaron, J., Rees, T., Betts, S. and Vincentelli, M. (1994) Our Sisters' Land: The Changing Identities of Women in Wales, Cardiff: University of Wales Press. Anderson, G. L. (2002) 'Reflecting on research for doctoral students in education', Education Researcher, vol 31(7), pp. 22-25.

Armstrong, L. (2007) 'The significance of interpersonal skills and tutor behaviour in determining quality of teaching and learning in adult education', Journal of Adult and Continuing Education, vol 13(2), pp. 231-248.

Baker, J. (2008) 'The ideology of choice. Overstating progress and hiding injustice in the lives of young women: Findings from a study in North Queensland, Australia', Women's Studies International Forum, vol 31(1), pp. 53-64.

Bamber, J. and Tett, L. (1999) 'Opening the doors of higher education to working class adults: A case study', International Journal of Lifelong Education, vol 18(6), pp. 465-475.

Bamber, J., Galloway, V. and Tett, L. (2006) 'Widening participation and metalearning: Risking less in higher education', Journal of Adult and Continuing Education, vol 12(1), pp. 20-33.

Benn, M. (1998) Madonna and Child: Towards a New Politics of Motherhood, London: Jonathan Cape.

Bick, E. (1987) 'The experience of the skin in early object relations', in M. H. Williams (ed.) Collected Papers of Martha Harris and Esther Bick, Perthshire: Clunie Press for Roland Harris Trust.

Bolam, H. and Dodgson, R. (2003) 'Retaining and supporting mature students in higher education', Journal of Adult and Continuing Education, vol 8(2), pp. 179-194. 
Bott, E. (1971) Family and Social Network: Roles, Norms, and External Relationships in Ordinary Urban Families, London: Tavistock.

Britton, C. and Baxter, A. (2001) 'Risk, identity and change: Becoming a mature student', International Studies in Sociology of Education, vol 11(1), pp. 87102.

Bullock, H. E. and Limbert, W. M. (2003) 'Scaling the socioeconomic ladder: Lowincome women's perceptions of class status and opportunity', Journal of Social Issues, vol 59(4), pp. 693-709.

Butler, J. (2004) Undoing Gender, Abingdon: Routledge.

Crosling, G., Thomas, L. and Heagney, M. (2008) Improving Student Retention in Higher Education: The Role of Teaching and Learning, London: Routledge. Davidoff, L. (1976) 'The rationalization of housework', in D. Leonard Barker and S. Allen (eds) Dependence and Exploitation in Work and Marriage, London: Longman.

Davies, R., Drinkwater, S., Joll, C., Jones, M., Lloyd-Williams, H., Makepeace, J., Parhi, M., Parken, A., Robinson, C., Taylor, C. and Wass, V. (2011) Anatomy of Economic Inequality in Wales, Wales Institute of Social and Economic Research Data and Methods, Research Report Series WISERD/RSS/002.

Delamont, S. and Atkinson, P. (1995) Fighting Familiarity: Essays on Education and Ethnography, Cresskill, NJ: Hampton Press.

Evans, G. (2006) Educational Failure and Working Class White Children in Britain, London: Palgrave Macmillan.

Furlong, A. and Cartmel, F. (1997) Young People and Social Change: Individualisation and Risk in Late Modernity, Buckingham: Open University Press. 
Gallacher, T. (2006) 'Blurring the boundaries: Blurring the boundaries or creating diversity? The contribution of the further education colleges to higher education in Scotland', Journal of Further and Higher Education, vol 30(1), pp. 43-58.

Gauntlett, D. (2007) Creative Explorations: New Approaches to Identities and Audiences, London: Routledge.

Gee, J. P. (2003) What Video Games have to Teach us about Learning and Literacy, New York: Palgrave Macmillan.

Giddens, A. (1991) Modernity and Self-identity: Self and Society in the Late Modern Age, Cambridge: Polity.

Goffman, E. (1959) The Presentation of Self in Everyday Life, Harmondsworth: Pelican.

Henriques, J., Hollway, W., Urwin, C., Couze, V., and Walkerdine, W. (1984) Changing the Subject: Psychology, Social Regulation and Subjectivity, London: Routledge.

Herod, A. and Aguiar, L. (2006) 'Introduction: Cleaners and the dirty work of neoliberalism', Antipode, vol 38(3), pp. 425-434.

Hewitt, L., Hall, E. and Mills, S. (2010) ‘Women learning: Women's learning: An investigation into the creation of learner identities', Widening Participation and Lifelong Learning, vol 12, pp. 91-102.

Hill, M. and Hatt, S. (2012) Review of Widening Access and Reaching Wider Strategies in Wales, York: Higher Education Academy.

Hills, J., Brewer, M., Jenkins, S., Lister, R., Lupton, R., Machin, S., Mills, C., Modood, T., Reese, T. and Riddell, S. (2010) An Anatomy of Economic 
Inequality in the UK: Report of the National Equality Panel, London: Government Equalities Office.

Holloway, W. (2006) The Capacity to Care: Gender and Ethical Subjectivity, London: Routledge.

Jephcote, M., Salisbury, J. and Rees, G. (2008) 'Being a further education teacher in changing times', Research in Post-Compulsory Education, vol 13(2), pp. 163172.

Jephcote, M., Salisbury, J. and Rees, G. (2009) 'The learning journey: Students' experiences of further education in Wales', Contemporary Wales, vol 22(1), pp. $141-157$.

Jones, R. (2008) Student Retention and Success: A Synthesis of Research, York: Higher Education Academy.

Kaomea, J. (2003) 'Reading erasures and making the familiar strange: Defamiliarising methods for research in formerly colonized and historically oppressed communities', Educational Researcher, vol 32(2), pp. 14-25.

Karach, A. (1992) 'The politics of dislocation: Some mature undergraduate women's experiences of higher education' Women's Studies International Forum, vol 15 (2), pp. 309-317.

Lucey, H., Melody, J. and Walkerdine, V. (2003) 'Uneasy hybrids: Psychological aspects of becoming educationally successful for working-class young women', Gender and Education, vol 15(3) pp. 285-299.

Mannay, D. (2010) 'Making the familiar strange: Can visual research methods render the familiar setting more perceptible?', Qualitative Research, vol 10(1), pp. $91-111$. 
Mannay, D. (2011) 'Taking refuge in the branches of a guava tree: The difficulty of retaining consenting and non-consenting participants' confidentiality as an indigenous researcher', Qualitative Inquiry, vol 17(10), pp. 962-964.

Mannay, D. (2013a) “"Keeping close and spoiling”: exploring the significance of 'home' for family relationships and educational trajectories in a marginalised estate in urban south Wales', Gender and Education, vol 25(1), pp. 91-107.

Mannay, D. (2013b). The permeating presence of past domestic and familial violence: So like I'd never let anyone hit me but I've hit them, and I shouldn't have done In J. Ribbens McCarthy, Hooper, C. and Gillies, V. (eds) Family Troubles? Exploring Changes and Challenges in the Family Lives of Children and Young People. Bristol: Policy Press.

Marandet, E. and Wainwright, E. (2006) 'An analysis of the learning needs and experiences of students with dependent children at Brunel University', Brunel University, available online at www.brunel.ac.uk/840/GES/LTDUFinalreport.pdf

Massey, D. (1994) Space, Place and Gender, Cambridge: Polity Press.

Maushart, S. (2001) Wifework: What Marriage Really Means for Women, London: Bloomsbury.

May, V. (2008) 'On being a "good" mother: The moral presentation of self in written life stories', Sociology, vol 42(3), pp. 470-486.

Milburn, A. (2012) University Challenge: How Higher Education can Advance Social Mobility - A Progress Report by the Independent Reviewer on Social Mobility and Child Poverty, London: Crown. 
Moore, J. and Dunworth, F. (2011) Review of Evidence from Aimhigher Area Partnerships of the Impact of Aimhigher, Manchester: Aimhigher Research Network.

Osborne, M., Marks, A. and Turner, E. (2004) 'Becoming a mature student: How older potential applicants weigh the advantages and disadvantages of embarking on a university course', Higher Education, vol 48(3), pp. 291-315.

Page, E. and Jha, J. (eds) (2009) Exploring the Bias: Gender and Stereotyping in Secondary Schools, London: Commonwealth Secretariat.

Parr, J. (1998) ‘Theoretical voices and women's own voices: The stories of mature women students', in J. Ribbens and R. Edwards (eds) Feminist Dilemmas in Qualitative Research: Public Knowledge and Private Lives, London: Sage.

Pilcher, J. (1994) 'Who should do the dishes? Three generations of Welsh women talking about men and housework', in J. Aaron, T. Rees, S. Betts and M. Vincentelli, Our Sisters' Land: The Changing Identities of Women in Wales, Cardiff: University of Wales Press.

Pilcher, J. (1999) Women in Contemporary Britain, London: Routledge.

Pole, C. (2007) 'Researching children and fashion: An embodied ethnography', Childhood, vol 14(1), pp. 67-84.

Reay, D. (2004) 'Mostly roughs and toughs: Social class, race and representation in inner city schooling', Sociology, vol 38(5), pp. 1005-1023.

Reay, D., Crozier, G. and Clayton, J. (2010) “"Fitting in” or "standing out": Workingclass students in UK higher education', British Educational Research Journal, vol 32(1), pp. 1-19.

Rees, T. (1988) 'Changing patterns of women's work in Wales: Some myths explored', Contemporary Wales, vol 2, 119-130. 
Rose, G. (2001) Visual Methodologies, London: Sage.

Skeggs, B. (1997) Formations of Class and Gender, London: Sage.

Sutton, L. (2009) 'They'd only call you scally if you are poor: The impact of socioeconomic status on children's identities', Children's Geographies, vol 7(3), pp. 277-290.

Thomas, L. and Jamieson-Ball, C. (2011) Engaging Students to Improve Student Retention and Success in Higher Education in Wales, York: Higher Education Academy.

Thompson, R., Henderson, S. and Holland, J. (2003) 'Making the most of what you've got? Resources, values and inequalities in young women's transitions to adulthood', Educational Review, vol 55(1), pp. 33-46.

Toynbee, P. (2003) Hard Work: Life in Low Pay Britain, London: Bloomsbury.

Walkerdine, V. (2010) 'Communal beingness and affect: An exploration of trauma in an ex-industrial community', Body and Society, vol 16(1), pp. 91-116.

Walkerdine, V. (2011) 'Neoliberalism, working-class subjects and higher education', Contemporary Social Science, vol 6(2), pp. 255-271.

Walkerdine, V. and Lucey, H. (1989) Democracy in the Kitchen, London: Virago.

Walkerdine, V. and Jimenez, L. (2012) Gender Work and Community after Deindustrialisation: A Psychosocial Approach to Affect, Basingstoke: Palgrave Macmillan.

Walkerdine, V., Lucey, H. and Melody, J. (2001) Growing Up Girl, Basingstoke: Palgrave.

Warren, T. (2003) 'Class and gender-based working time? Time poverty and the division of domestic labour', Sociology, vol 37(4), pp. 733-752. 
Warrington, M. (2005) 'Mirage in the desert? Access to educational opportunities in an area of social exclusion', Antipode, vol 37(4), pp. 796-816.

Welsh Assembly Government (2008) Welsh Index of Multiple Deprivation 2008:

Summary Report, Cardiff: Welsh Assembly Government. 